\title{
A simulation model for nitrogen retention in a papyrus wetland near Lake Victoria, Uganda (East Africa)
}

\author{
A. A. van Dam · A. Dardona · P. Kelderman · \\ F. Kansiime
}

Received: 25 August 2006/Accepted: 9 May 2007/Published online: 12 June 2007

(C) Springer Science+Business Media B.V. 2007

\begin{abstract}
Papyrus wetlands around Lake Victoria, East Africa play an important role in the nutrient flows from the catchment to the lake. A dynamic model for nitrogen cycling was constructed to understand the processes contributing to nitrogen retention in the wetland and to evaluate the effects of papyrus harvesting on the nitrogen absorption capacity of the wetlands. The model had four layers: papyrus mat, water, sludge and sediment. Papyrus growth was modelled as the difference between nitrogen uptake and loss. Nitrogen uptake was modelled with a logistic equation combined with a Monod-type nitrogen limitation. Nitrogen compartments were papyrus plants, organic material in the floating mat; and total ammonia, nitrate and organic nitrogen in the water, sludge and sediment. Apart from the uptake and decay rates of the papyrus, the model included sloughing and settling of mat material into the water, mineralization of organic matter, and nitrification and diffusion of dissolved inorganic nitrogen. Literature data and field
\end{abstract}

A. A. van Dam $(\varangle)$ · A. Dardona · P. Kelderman

Department of Environmental Resources,

UNESCO-IHE Institute for Water Education,

P.O.Box 3015, 2601 DA Delft, The Netherlands

e-mail: a.vandam@unesco-ihe.org

F. Kansiime

Makerere University Institute of Environment

and Natural Resources, Kampala, Uganda measurements were used for parameterization. The model was calibrated with data from Kirinya wetland in Jinja, Uganda which receives effluent from a municipal wastewater treatment plant. The model simulated realistic concentrations of dissolved nitrogen with a stable biomass density of papyrus and predicted accumulation of organic sludge in the wetland. Assuming that this sludge is not washed out of the wetland, the overall nitrogen retention of the wetland over a three-year period was $21.5 \mathrm{~g} \mathrm{~N}$ $\mathrm{m}^{-2}$ year $^{-1}$ or about $25 \%$ of input. Harvesting 10, 20 and $30 \%$ of the papyrus biomass per year increased nitrogen retention capacity of the wetland to 32.3, 36.8 and $38.1 \mathrm{~g} \mathrm{~m}^{-2}$ year $^{-1}$, respectively. Although the nutrient flows estimated by the model are within the ranges found in other papyrus wetlands, the model could be improved with regard to the dynamics of detrital nitrogen. Actual net retention of nitrogen in the sludge is likely to be lower than $21.5 \mathrm{~g} \mathrm{~N}$ $\mathrm{m}^{-2}$ year ${ }^{-1}$ because of flushing out of the sludge to the lake during the rainy season.

Keywords Nitrogen - Lake Victoria - Wetlands . Modelling $\cdot$ Nitrogen retention $\cdot$ Buffering capacity

\section{Introduction}

Lake Victoria is very important for the livelihoods of millions of people in East Africa. The extensive 
wetland ecosystem fringing the lake is covered by several species of wetland macrophytes, such as Cyperus papyrus L. and Phragmites mauritianus Kunth. which are used for making mats, roofs and other materials (Kaggwa et al. 2005; Kipkemboi et al. 2006). Seasonal flood-retreat agriculture and fishing are other important direct use values of these wetlands (Gichuki et al. 2001; Denny et al. 2006). In addition to the direct use values, the wetlands along the lakeshore also provide important ecosystem services. Their huge swampy areas work as giant filters, removing silt, nutrients, heavy metals and other polllutants from the water before it enters the lake.

However, the wetlands are threatened by pollution from domestic and industrial sources, by destruction for agricultural production and by overexploitation for papyrus and fish harvesting. In the past decades, population increase and the migration of people to the lake region have led to wetland destruction and degradation. Over-exploitation and destruction of wetland vegetation curtail the filter function of wetlands as pollutants and nutrients are carried directly into the lake when the vegetation of wetland macrophytes is destroyed (Okeyo-Owuor 1999; Odada et al. 2004). To formulate sustainable management strategies, trade-offs between socio-economic and ecological indicators need to be made (McCartney et al. 2005) based on a good understanding of the hydrological and ecological (including nutrient retention and buffering) mechanisms underlying wetland functioning.

This study focuses on the nitrogen flows through a floating papyrus wetland using a dynamic simulation model based on knowledge of nitrogen cycle processes. The model examines the nitrogen cycle of several components within the floating wetland, including the wetland vegetation, the water column, the water-sediment interface and the sediment. The objectives of the model are: (1) to describe the floating papyrus wetland ecosystem and the nitrogen transformations in the wetland; (2) to understand the processes contributing to nitrogen retention capacity of the wetland; and (3) to evaluate the effects of potential management strategies (notably harvesting of vegetation) on the nutrient absorption capacity of the wetland.

\section{Methods}

Review of literature

The wetlands fringing Lake Victoria are dominated by a small number of macrophyte species, including papyrus (Cyperus papyrus), Miscanthidium violaceum, Phragmites mauritianus and Typha domingensis (Gichuki et al. 2001). Large portions of these wetlands are dominated by stands of papyrus, that can occur in two distinct functional types: rooted and floating. In its rooted form, the papyrus is attached to the sediment from which the roots absorb nutrients. When rooted stands detach from the sediment (e.g., by wave action), they form floating mats consisting of interweaved roots and rhizomes floating on the water and forming the basis for the standing biomass of papyrus culms and umbels (Kansiime and Nalubega 1999). In a typical stand of papyrus, mature culms with umbel can reach a height of $5 \mathrm{~m}$ and are mixed with younger shoots in various stages of development. Between the rootz and rhizomes, organic detritus from decaying dead plants accumulates. In this paper, the standing biomass of culms and umbels is equivalent to what in rooted papyrus would be called the aboveground biomass. The floating mat consists of rhizome, roots and detrital deposits.

A review of current publications regarding the structure and function of papyrus wetlands in East Africa showed that the aboveground standing biomass ranged from about 1000 to more than $6000 \mathrm{~g}$ dry matter (dm) m ${ }^{-2}$ (Gaudet 1975; Gaudet 1977; Gaudet 1979; Thompson et al. 1979; Jones and Muthuri 1985; Muthuri et al. 1989; Jones and Muthuri 1997; Muthuri and Jones 1997; Kansiime and Nalubega 1999; Kipkemboi et al. 2002; Okurut 2000). The belowground biomass component of papyrus wetlands has been studied less extensively, however some measurements of live rhizome and root sections have been made. Kipkemboi et al. (2002) measured an average biomass of $1296 \mathrm{~g} \mathrm{dm}$ $\mathrm{m}^{-2}$ in Nakivubo, Gogonya and Namiiro wetlands in Uganda, while Jones and Muthuri (1997) measured $4516 \mathrm{~g} \mathrm{dm} \mathrm{m}^{-2}$ in Lake Naivasha. For the whole mat, including the rhizome, roots and detrital deposits, measurements range from 8,140 to $180,000 \mathrm{~g} \mathrm{dm}$ $\mathrm{m}^{-2}$ (Jones and Muthuri 1997; Okurut 2000). 
Measurements of papyrus productivity in natural wetlands range from $7.7 \mathrm{~g} \mathrm{dm} \mathrm{m}^{-2} \mathrm{~d}^{-1}$ to $38 \mathrm{~g} \mathrm{dm}$ $\mathrm{m}^{-2} \mathrm{~d}^{-1}$. The lowest measurements of NPP, $7.7 \mathrm{~g} \mathrm{dm} \mathrm{m}^{-2} \mathrm{~d}^{-1}$ were recorded in the Upemba basin, Democratic Republic of Congo (Thompson et al. 1979). Average values of 14.1 and $21.0 \mathrm{~g} \mathrm{dm}$ $\mathrm{m}^{-2} \mathrm{~d}^{-1}$ were recorded in an undisturbed and a previously harvested swamp, respectively in Lake Naivasha, Kenya (Muthuri et al. 1989) while the highest NPP values of $31-38 \mathrm{~g} \mathrm{dm} \mathrm{m}^{-2} \mathrm{~d}^{-1}$ were recorded in the Nakivubo swamp, Uganda (Kansiime and Nalubega 1999). Even higher productivity values of $32.6-65.4 \mathrm{~g} \mathrm{dm} \mathrm{m}^{-2} \mathrm{~d}^{-1}$ were observed in a constructed wetland in Jinja, Uganda (Okurut 2000). Experimentally determined nitrogen uptake rates from papyrus wetlands varied from $0.030 \mathrm{~g} \mathrm{~N}$ $\mathrm{m}^{-2} \mathrm{~d}^{-1}$ to $0.71 \mathrm{~g} \mathrm{~N} \mathrm{~m}^{-2} \mathrm{~d}^{-1}$ (the latter during the exponential growth phase in a constructed wetland; Okurut 2000), but measured values in natural wetlands ranged between $0.047 \mathrm{~g} \mathrm{~N} \mathrm{~m}^{-2} \mathrm{~d}^{-1}$ and $0.21 \mathrm{~g} \mathrm{~N} \mathrm{~m}^{-2} \mathrm{~d}^{-1}$ (Kawaga, Uganda: Gaudet 1977; Lake Naivasha, Kenya: Muthuri et al. 1989; Nakivubo, Uganda: Kansiime and Nalubega 1999).

Model structure and equations

The nitrogen model has four layers: vegetation, water, sludge and sediment (Fig. 1). Main state variables are: total papyrus biomass (standing biomass plus rhizome and roots); papyrus mat detritus (the detrital deposits in the papyrus mat); organic nitrogen, total ammonia and nitrate nitrogen in the water column $\left(\mathrm{ON}_{\mathrm{w}}, \mathrm{TAN}_{\mathrm{w}}\right.$ and $\left.\mathrm{NO}_{\mathrm{w}}\right)$; organic nitrogen, total ammonia and nitrate nitrogen in the sludge $\left(\mathrm{ON}_{\mathrm{sl}}, \mathrm{TAN}_{\mathrm{sl}}\right.$ and $\left.\mathrm{NO}_{\mathrm{sl}}\right)$; and total ammonia and nitrate nitrogen in the sediment $\left(\mathrm{TAN}_{\mathrm{sed}}\right.$ and $\mathrm{NO}_{\text {sed }}$ ). The sludge layer is the interface layer between the water column and the sediment, where particulate organic matter from the floating papyrus mat settles and forms a loose flocculent layer. Concentrations of dissolved nutrients in this layer may be higher than in the water column, but diffusion, resuspension of organic matter and advective flows constantly reduce the concentration gradients. On the other hand, organic matter at the sludgesediment interface in time becomes buried in the sediment/peat layer. Dissolved nitrogen from the sludge layer may diffuse to the sediment pore water. Ammonia from the pore water can be adsorbed to the soil particles. The major transformation pathways are nitrification, uptake by plants, plant mortality, mineralization of organic nitrogen, settling of detritus to the sediment sludge, denitrification, and remineralisation of organic nitrogen from the sludge (Fig. 1).

Plant nitrogen growth was modelled as the balance of nitrogen uptake by the plants, and the decay (mortality) and harvesting of the plants:

$$
\begin{aligned}
\text { papyrus } \mathrm{N} \text { growth }= & \text { total } \mathrm{N} \text { uptake }- \text { decay } \\
& - \text { harvesting }
\end{aligned}
$$

Fig. 1 Conceptual model of nitrogen cycling in a floating papyrus wetland. The dotted boxes for organic nitrogen in the sediment layer and ammonia adsorbed to sediment particles indicate that these variables are not estimated in the model (see text for further explanation)

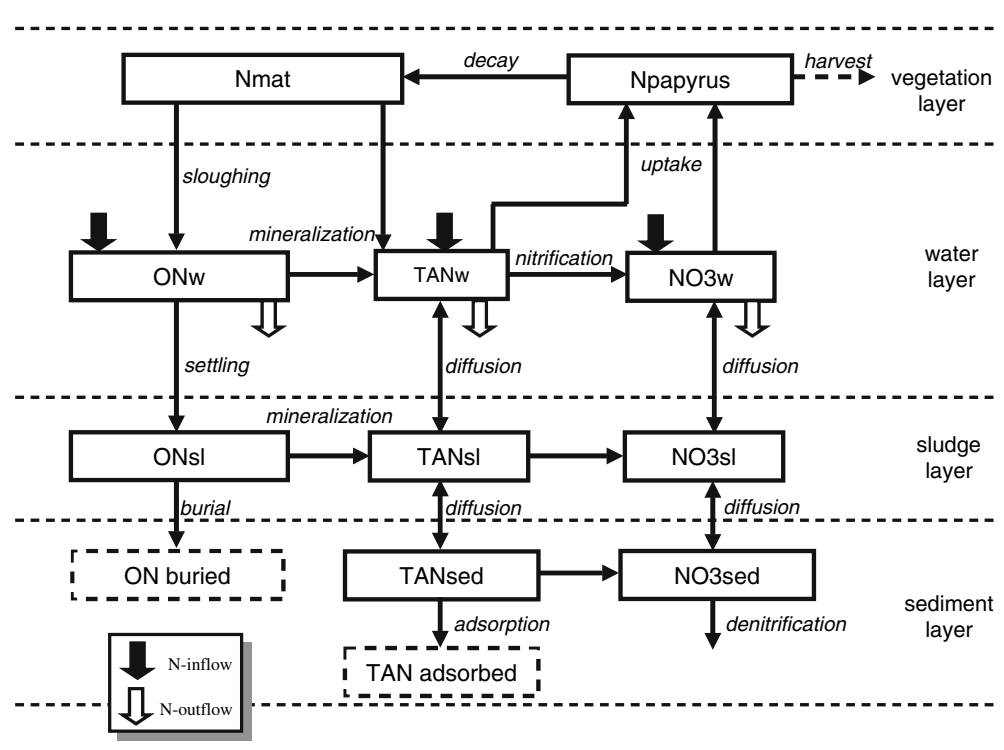


Total $\mathrm{N}$ uptake was modelled as the sum of ammonia and nitrate uptake by the plants. For ammonium uptake, the maximum uptake rate of the plants was limited by the concentration of TAN in the water layer (Monod-type equation with half saturation constant) and by a maximum plant $\mathrm{N}$ density (logistic equation):

$$
\begin{aligned}
\text { Uptake }_{\mathrm{TAN}}= & \text { Maxuptake }_{\mathrm{TAN}} \cdot \mathrm{N}_{\text {papyrus }} \\
& \cdot\left(1-\frac{\mathrm{N}_{\text {papyrus }}}{\text { NMAX }_{\text {papyrus }}}\right) \\
& \cdot\left(\frac{\text { Conc }_{\mathrm{TANw}}}{\text { Conc }_{\mathrm{TANw}}+\mathrm{K}_{\mathrm{TANw}}}\right)
\end{aligned}
$$

in which Maxuptake TAN $_{\text {is }}$ the maximum uptake of

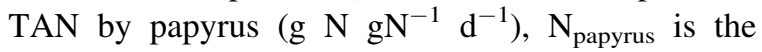
nitrogen in papyrus biomass $(\mathrm{g}), \mathrm{NMAX}_{\text {papyrus }}$ is the theoretical maximum value of nitrogen in papyrus biomass (or carrying capacity, in g), Conc $_{\text {TANw }}$ is the concentration of TAN in the water $\left(\mathrm{g} \mathrm{m}^{-3}\right)$, and $\mathrm{K}_{\text {TANw }}$ is the half saturation constant for TAN uptake by papyrus $\left(\mathrm{g} \mathrm{m}^{-3}\right)$. For nitrate uptake, a similar equation was used.

Harvesting, nitrification, plant mortality, mineralization of detritus, denitrification and settling of detritus were modelled as first-order reactions, for example mineralization of $\mathrm{ON}_{\mathrm{w}}$ was modelled as:

Mineralization $_{\mathrm{ONw}}=\mathrm{ON}_{\mathrm{w}} \cdot \mathrm{K}_{\min }$

in which $\mathrm{ON}_{\mathrm{w}}$ is the organic nitrogen in the water $(\mathrm{g})$ and $\mathrm{K}_{\min }$ is the first-order rate constant for mineralization of organic matter in the water column $\left(\mathrm{d}^{-1}\right)$.

Diffusion of dissolved nutrients across the watersludge interface and the sludge-sediment interface was modelled with an equation based on Fick's second law (Jiménez-Montealegre et al. 2002). For example Eq. 4 describes the rate of TAN diffusion across the sludge-water interface:

$$
\begin{aligned}
\text { Diffusion }_{\mathrm{TAN}}= & \mathrm{K}_{\mathrm{diff}, \mathrm{TAN}} \\
& \cdot\left(\frac{\text { Conc }_{\mathrm{TANW}}-\text { Conc }_{\mathrm{TANsl}}}{\mathrm{D}}\right) \cdot A
\end{aligned}
$$

in which $\mathrm{K}_{\text {diff }}$ is the diffusion rate constant for TAN across the sludge-water interface $\left(\mathrm{m}^{2} \mathrm{~d}^{-1}\right)$, Conc TANw $_{\text {. }}$ and Conc $_{\text {TANsl }}$ are the concentrations of TAN in water and sludge layer, respectively $\left(\mathrm{g} \mathrm{m}^{-3}\right), \mathrm{D}$ is the depth of the sludge layer $(\mathrm{m})$ and $\mathrm{A}$ is the surface area of the wetland sediment $\left(\mathrm{m}^{2}\right)$. A complete list of all parameters and rate constants used is given in Table 1.

Model assumptions and implementation

Data from the Kirinya wetland in Jinja, Uganda were used to calibrate the model. Water temperature in the wetland ranged from 21 to $26^{\circ} \mathrm{C}$ but showed little seasonal variation. Dissolved oxygen (DO) concentrations were mostly between $0 \mathrm{~g} \mathrm{~m}^{-3}$ and $1 \mathrm{~g} \mathrm{~m}^{-3}$. In the model, temperature and DO were assumed to be constant and were not included as variables in the model. TAN volatilization was assumed to be unimportant because of the low $\mathrm{pH}$ in the wetland and the fact that most of the water surface is covered by the papyrus mat. Model parameterization was conducted using a combination of direct measurements in the Kirinya wetland between 2000 and 2003 (Kansiime and Mwesigye 2003; Kelderman et al. 2007), and literature values on papyrus wetland ecology and nitrogen cycling in aquatic systems (Delincé 1992; Jamu 1998; Jiménez-Montealegre 2001; Jørgensen and Bendoricchio 2001; Jamu and Piedrahita 2002; Jiménez-Montealegre et al. 2002). Simulations were based on the western zone of the Kirinya wetland which has an estimated surface area of 147,000 $\mathrm{m}^{2}$. Data from Kansiime and Mwesigye (2003) showed that the discharge from the municipal wastewater plant followed a preferential flow path through this part of the wetland, justifying the use of this area as the basis for the model simulations.

To run the model, an artificial one-year rainfall and evaporation scenario was constructed by taking average values from meteorological data from weather stations in Gaba, Kampala and Jinja (R.C. Kaggwa, personal communication). The average inflow into the wetland was assumed to be $1,500 \mathrm{~m}^{3} \mathrm{~d}^{-1}$ (F. Kansiime, personal communication). The model then calculated the outflow from the difference between inflow, evapotranspiration and rainfall (see Fig. 2).

The concentrations of TAN, NO3 and ON in the inflow were set at $15,0.5$ and $10 \mathrm{~g} \mathrm{~m}^{-3}$, respectively based on field measurements in Kirinya. The initial plant biomass was set at $9800 \mathrm{~g} \mathrm{dm} \mathrm{m}^{-2}$. The initial detrital mass of the floating mat (dead plant material) was assumed to be two times the plant biomass (culms, umbels, roots, rhizome). The initial sludge density was assumed to be equal to the initial detrital 
Table 1 Parameter values, initial conditions and wetland dimensions in the model

\begin{tabular}{|c|c|c|}
\hline Parameter & Value & Unit \\
\hline \multicolumn{3}{|l|}{ Process constants } \\
\hline K TAN (half saturation constant) & 0.7 & $\mathrm{~g} \mathrm{~m}^{-3}$ \\
\hline K NO3 (half saturation constant) & 0.1 & $\mathrm{~g} \mathrm{~m}^{-3}$ \\
\hline Max TAN uptake rate of papyrus & $5 e-2$ & $\mathrm{~d}^{-1}$ \\
\hline Max NO3 uptake rate of papyrus & $5 e-2$ & $\mathrm{~d}^{-1}$ \\
\hline Maximum papyrus biomass & 10,000 & $\mathrm{~g} \mathrm{dm} \mathrm{m}^{-2}$ \\
\hline K decay & $1.1 \mathrm{e}-3$ & $\mathrm{~d}^{-1}$ \\
\hline K sloughing & $6.25 \mathrm{e}-4$ & $\mathrm{~d}^{-1}$ \\
\hline $\mathrm{K}$ mineralization water & $2 \mathrm{e}-4$ & $\mathrm{~d}^{-1}$ \\
\hline $\mathrm{K}$ settling & $5 e-3$ & $\mathrm{~d}^{-1}$ \\
\hline $\mathrm{K}$ mineralization sludge & $2 \mathrm{e}-4$ & $\mathrm{~d}^{-1}$ \\
\hline $\mathrm{K}$ burial & $1 e-3$ & $\mathrm{~d}^{-1}$ \\
\hline $\mathrm{K}$ nitrification sludge & $5 e-3$ & $\mathrm{~d}^{-1}$ \\
\hline $\mathrm{K}$ nitrification sediment & $5 e-4$ & $\mathrm{~d}^{-1}$ \\
\hline $\mathrm{K}$ nitrification water & $5 e-3$ & $\mathrm{~d}^{-1}$ \\
\hline $\mathrm{K}$ diffusion TAN sludge-water & $2.5 \mathrm{e}-4$ & $\mathrm{~m}^{2} \mathrm{~d}^{-1}$ \\
\hline $\mathrm{K}$ diffusion TAN sludge-sediment & $2.5 \mathrm{e}-4$ & $\mathrm{~m}^{2} \mathrm{~d}^{-1}$ \\
\hline $\mathrm{K}$ diffusion NO3 sludge-water & $2.5 \mathrm{e}-4$ & $\mathrm{~m}^{2} \mathrm{~d}^{-1}$ \\
\hline $\mathrm{K}$ diffusion NO3 sludge-sediment & $2.5 \mathrm{e}-4$ & $\mathrm{~m}^{2} \mathrm{~d}^{-1}$ \\
\hline Papyrus N content & 1.5 & $\% \mathrm{dm}$ \\
\hline Mat $\mathrm{N}$ content & 1.0 & $\% \mathrm{dm}$ \\
\hline Sludge $\mathrm{N}$ content & 0.2 & $\% \mathrm{dm}$ \\
\hline \multicolumn{3}{|l|}{ Initial conditions } \\
\hline Concentration of TAN inflow & 15 & $\mathrm{~g} \mathrm{~m}^{-3}$ \\
\hline Concentration of $\mathrm{NO} 3$ inflow & 0.5 & $\mathrm{~g} \mathrm{~m}^{-3}$ \\
\hline Concentration of ON inflow & 10 & $\mathrm{~g} \mathrm{~m}^{-3}$ \\
\hline Initial papyrus biomass & 9,800 & $\mathrm{~g} \mathrm{~m}^{-3}$ \\
\hline Initial mat mass & 19,600 & $\mathrm{~g} \mathrm{~m}^{-3}$ \\
\hline Initial sludge mass & 19,600 & $\mathrm{~g} \mathrm{~m}^{-3}$ \\
\hline \multicolumn{3}{|l|}{ Wetland dimensions } \\
\hline Surface area (model zone) & 147,000 & $\mathrm{~m}^{2}$ \\
\hline Total water + sludge depth & 0.65 & $\mathrm{~m}$ \\
\hline Sediment depth & 0.30 & $\mathrm{~m}$ \\
\hline
\end{tabular}

mass density. The model was then run for three years (1,095 days) using Stella 7.0.2 (High Performance Systems, Inc., Hanover, NH, USA), with a time step of 0.125 day using Euler (rectangular) integration. For the simulation, it was assumed that the papyrus was in the stationary growth phase and therefore that biomass was more or less stable at a level of $10,000 \mathrm{~g} \mathrm{dm} \mathrm{m}^{-2}$. Calibration consisted of first adjusting the maximum nutrient uptake rates of TAN and NO3, and then all the other model parameters to achieve a stable papyrus biomass.

\section{Nitrogen balance and harvesting scenarios}

After calibration of the model, a nitrogen balance for the wetland was calculated by comparing the total nitrogen inflow (TAN, NO3 and ON) with nitrogen outflow and nitrogen accumulation in the wetland. All nitrogen flows were expressed in $\mathrm{mg} \mathrm{N} \mathrm{m}^{-2} \mathrm{~d}^{-1}$ and compared with literature values. Nitrogen retention by the wetland (in $\mathrm{g} \mathrm{m}^{-2}$ year $^{-1}$ ) was expressed as:

$\mathrm{N}$ retention $=\left(\frac{\text { total } \mathrm{N}_{\text {in }}-\text { total } \mathrm{N}_{\text {out }}}{\mathrm{A}}\right)$

in which total $\mathrm{N}_{\text {in }}$ is the amount of nitrogen flowing into the wetland $\left(\mathrm{g}\right.$ year ${ }^{-1}$ ), total $\mathrm{N}_{\text {out }}$ is the amount of nitrogen flowing out of the wetland into the lake $\left(\mathrm{g}_{\text {year }}{ }^{-1}\right)$ and $\mathrm{A}$ is the surface area of the wetland $\left(\mathrm{m}^{2}\right)$.

To evaluate the effect of papyrus harvesting on nitrogen retention, three harvesting scenarios were simulated: harvesting of $10 \%, 20 \%$ and $30 \%$ per year of the total standing/live papyrus biomass (i.e., $\mathrm{K}_{\text {harvesting }}$ of $0.0274,0.0548$ and $0.0822 \mathrm{~d}^{-1}$, respectively). The effect of harvesting on the nitrogen budget, nitrogen flows and nitrogen retention was estimated.

\section{Results}

Table 1 summarizes the parameter values used in the model. Figures 3-6 show the simulated floating mat and nitrogen state variables. With a stable biomass of papyrus vegetation and floating rhizome mat, it was possible to simulate concentrations of TAN and NO3 in the water that were similar to measured concentrations (Kansiime and Mwesigye 2003). Under these conditions, the model predicts a steady accumulation of organic nitrogen in the sludge layer of the wetland. The nitrogen budget calculated by the model is shown in Table 2 (first column). Of the total $40,158 \mathrm{~kg}$ of nitrogen entering the wetland area over a three year period, $30,673 \mathrm{~kg} \mathrm{~N}$ flowed out into the lake in the form of TAN and organic nitrogen. This resulted in an overall nitrogen retention of $21.5 \mathrm{~g} \mathrm{~N}$ $\mathrm{m}^{-2}$ year ${ }^{-1}$. The budget shows that most of the 
Fig. 2 Water balance in the wetland. Outflow was calculated as the balance of inflow, precipitation and evaporation assuming a constant total volume

Fig. 3 Floating detritus mat density (1: $\left.\mathrm{g} \mathrm{dm} \mathrm{m}^{-2}\right)$, bottom sludge density $\left(\mathrm{g} \mathrm{dm} \mathrm{m}^{-2}\right)$ and papyrus biomass density (3: $\mathrm{g} \mathrm{dm}$ $\mathrm{m}^{-2}$ ) in a zone of Kirinya wetland as simulated by the model

Fig. 4 Concentrations of total ammonia nitrogen (TAN) in the water (1), in the sludge (2) and in the sediment porewater (all in $\mathrm{g} \mathrm{m}^{-3}$ )
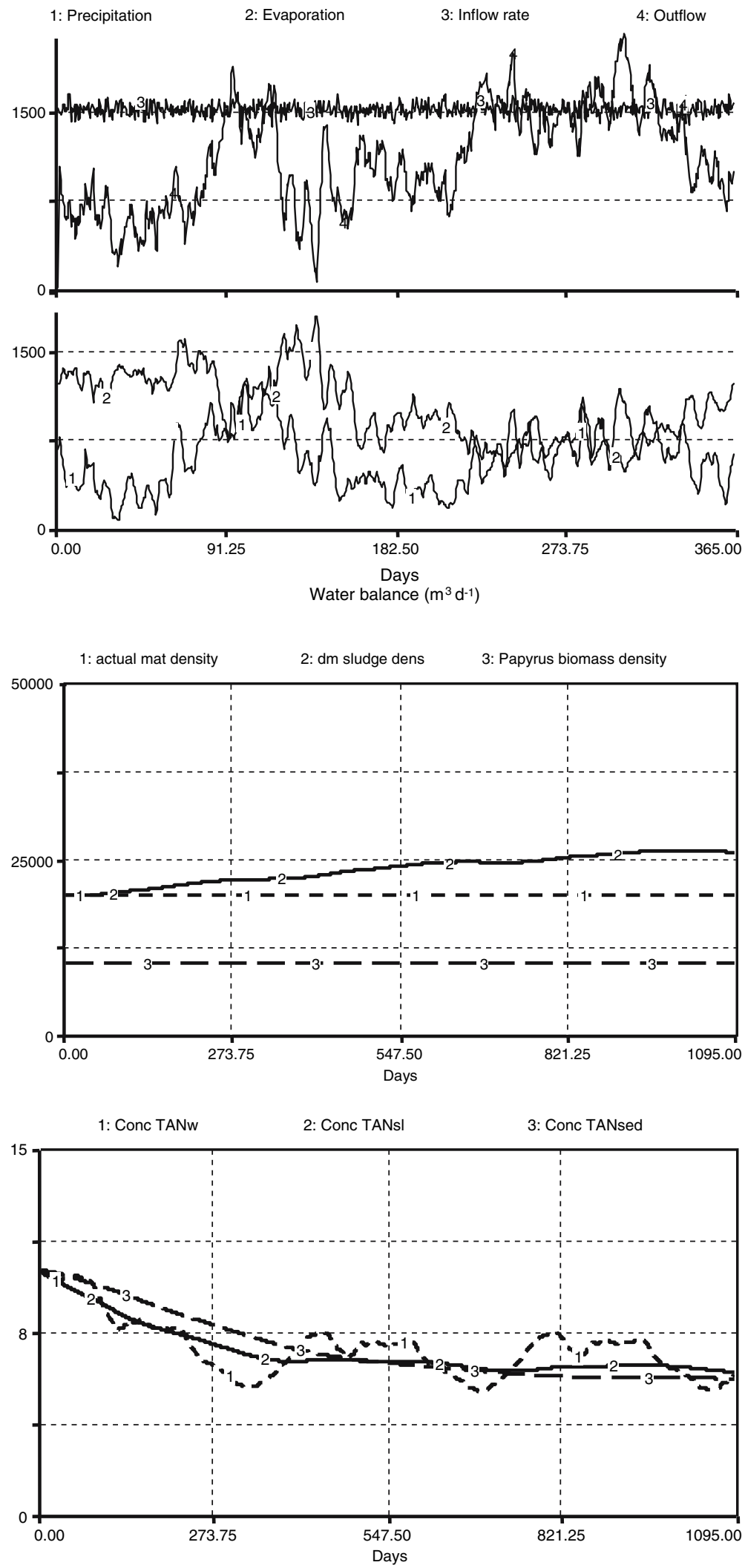
Fig. 5 Concentration of organic nitrogen in the water (1: ONw, in $\mathrm{g} \mathrm{m}^{-3}$ ) and density of organic nitrogen in sludge (2: ONsl, in $\mathrm{g} \mathrm{m}^{-2}$ ) as simulated by the model
Fig. 6 Concentration of nitrate nitrogen in the water (1: NO3w), in the sludge (NO3sl) and in the sediment pore water (NO3sed), all in $\mathrm{g} \mathrm{m}^{-3}$, as simulated by the model
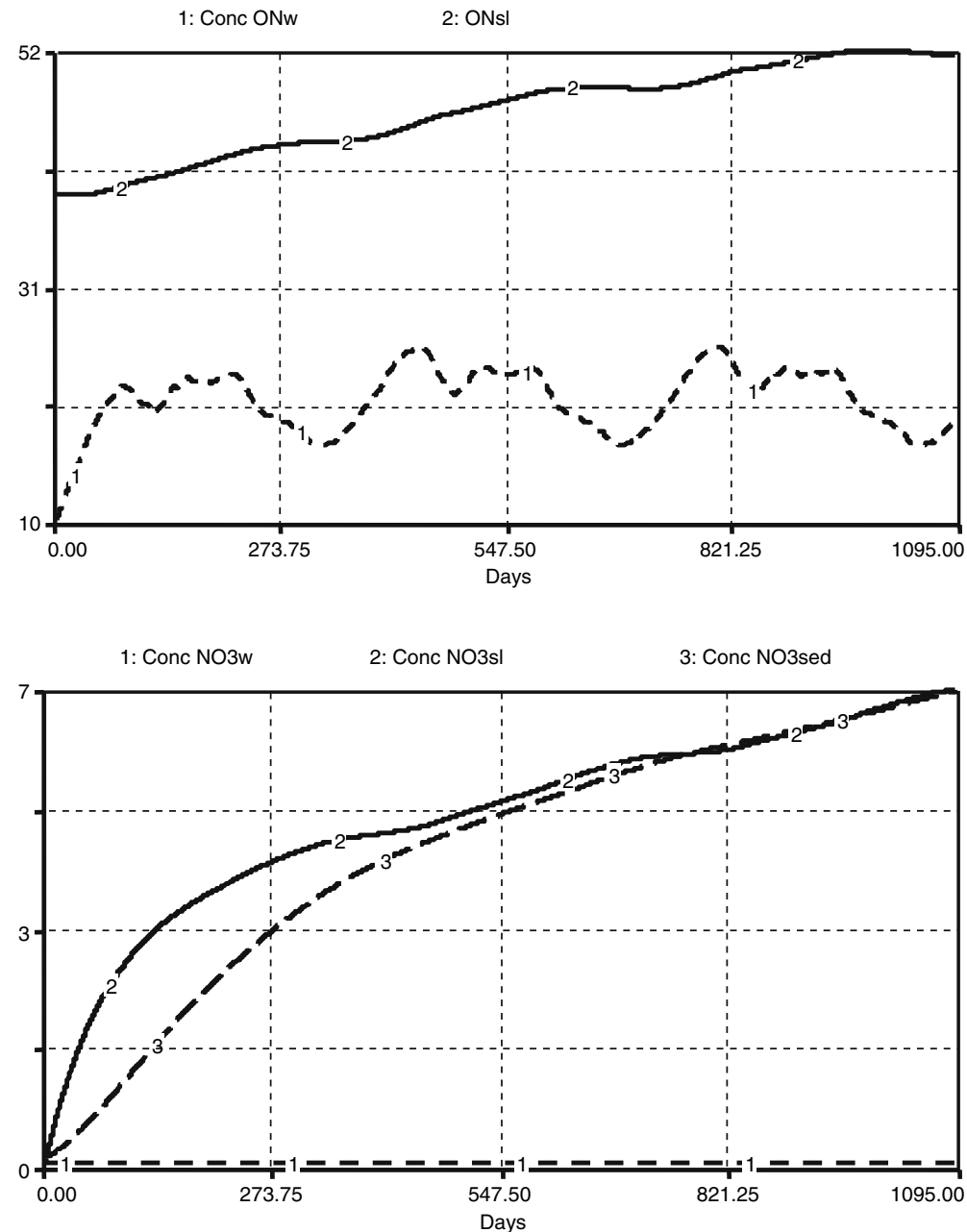

nitrogen retained accumulated in the sludge. The accumulation in plant biomass was negligible because the uptake of dissolved nitrogen by the papyrus only replaced nitrogen lost in plant mortality. On balance, plant biomass did not increase because the plants were in a stationary growth phase.

Table 2 shows the effects of harvesting on the nitrogen budget. Harvesting led to export of nitrogen from the system and reduced the biomass of the papyrus (Fig. 7). While harvesting 10\% per year resulted in a slightly reduced but stable papyrus biomass, harvesting $20 \%$ per year or more caused a steady decline in papyrus biomass. The reduction in biomass caused by the harvesting increased the uptake rate of dissolved nutrients (see Eq. 2). This resulted in lower concentrations of dissolved nitrogen in the water (Fig. 8). However, the effect of harvesting on TAN concentration decreased strongly with increased harvesting rate. The largest reduction in TAN concentration was achieved with harvesting $10 \%$ per year, while the difference between $20 \%$ and $30 \%$ harvesting per year was negligible (see Fig. 8). Harvesting did not affect the export of nitrogen in the form of organic nitrogen, nor did it change the accumulation of nitrogen in the sludge. Nitrogen retention increased with harvesting (see Table 2).

Table 3 shows the internal flows of nitrogen in the wetland for the four harvesting rates. Without harvesting, total uptake by the vegetation was $161.9 \mathrm{mg} \mathrm{N} \mathrm{m}^{-2} \mathrm{~d}^{-1}$. Because of the stable plant population, all of this nitrogen uptake was released into the mat through decay, and subsequently into the water through sloughing and mineralization. The rate 
Table 2 Nitrogen budget for Kirinya wetland based on the model

\begin{tabular}{|c|c|c|c|c|c|c|}
\hline \multicolumn{2}{|c|}{ Compartment } & \multicolumn{2}{|l|}{ No harvesting } & \multicolumn{3}{|c|}{ Harvesting $\left(\%\right.$ year $\left.^{-1}\right)$} \\
\hline & & \multirow{2}{*}{$\begin{array}{l}\mathrm{g} \mathrm{N} \text { in } 3 \text { years } \\
23,622,275\end{array}$} & \multirow[t]{2}{*}{$\begin{array}{l}\% \text { of total } \\
\mathrm{N} \text { input }\end{array}$} & \multirow[t]{2}{*}{$\begin{array}{l}10 \% \text { year }^{-1} \\
\% \text { of total } \mathrm{N} \text { input }\end{array}$} & \multirow[t]{2}{*}{$\begin{array}{l}20 \% \text { year }^{-1} \\
\% \text { of total } \mathrm{N} \text { input }\end{array}$} & $\begin{array}{l}30 \% \text { year }^{-1} \\
\% \text { of total } \mathrm{N} \text { input }\end{array}$ \\
\hline \multirow[t]{3}{*}{$\mathrm{N}_{\text {in }}$} & TAN & & & & & \\
\hline & NO3 & 787,409 & & & & \\
\hline & $\mathrm{ON}$ & $15,748,183$ & & & & \\
\hline \multirow[t]{10}{*}{$\mathrm{N}_{\text {accum }}$} & $\mathrm{N}_{\text {papyrus }}$ & 1,107 & 0.0 & -1.0 & -6.3 & -12.3 \\
\hline & $\mathrm{N}_{\text {mat }}$ & 14,167 & 0.0 & -0.6 & -3.2 & -6.5 \\
\hline & TANw & $-468,764$ & -1.2 & -2.1 & -2.3 & -2.4 \\
\hline & NO3w & $-7,027$ & 0.0 & 0.0 & 0.0 & 0.0 \\
\hline & $\mathrm{ONw}$ & 646,455 & 1.6 & 1.6 & 1.5 & 1.4 \\
\hline & TANsl & $-85,556$ & -0.2 & -0.5 & -0.6 & -0.6 \\
\hline & NO3sl & 326,619 & 0.8 & 0.5 & 0.4 & 0.4 \\
\hline & ONsl & $1,849,730$ & 4.6 & 4.6 & 4.4 & 4.3 \\
\hline & TANsed & $-137,849$ & -0.3 & -0.5 & -0.5 & -0.5 \\
\hline & NO3sed & 195,715 & 0.5 & 0.3 & 0.3 & 0.3 \\
\hline \multirow[t]{5}{*}{$\mathrm{N}_{\text {out }}$} & TANw & $7,468,173$ & 18.6 & 6.9 & 2.4 & 1.5 \\
\hline & NO3w & 36,387 & 0.1 & 0.0 & 0.0 & 0.0 \\
\hline & $\mathrm{ONw}$ & $23,168,585$ & 57.7 & 57.6 & 57.2 & 56.7 \\
\hline & Buried & $7,150,125$ & 17.8 & 17.8 & 17.8 & 17.7 \\
\hline & Harvest & 0 & 0.0 & 15.3 & 28.8 & 40.0 \\
\hline \multicolumn{2}{|c|}{$\mathrm{N}$ retention for lake $\left(\mathrm{g} \mathrm{m}^{-2}\right.$ year $\left.^{-1}\right)$} & & 21.5 & 32.3 & 36.8 & 38.1 \\
\hline
\end{tabular}

Fig. 7 Effect of harvesting (in $\%$ of biomass year ${ }^{-1}$ ) on the biomass of papyrus (in $\mathrm{g}$ $\mathrm{dm} \mathrm{m} \mathrm{m}^{-2}$ )

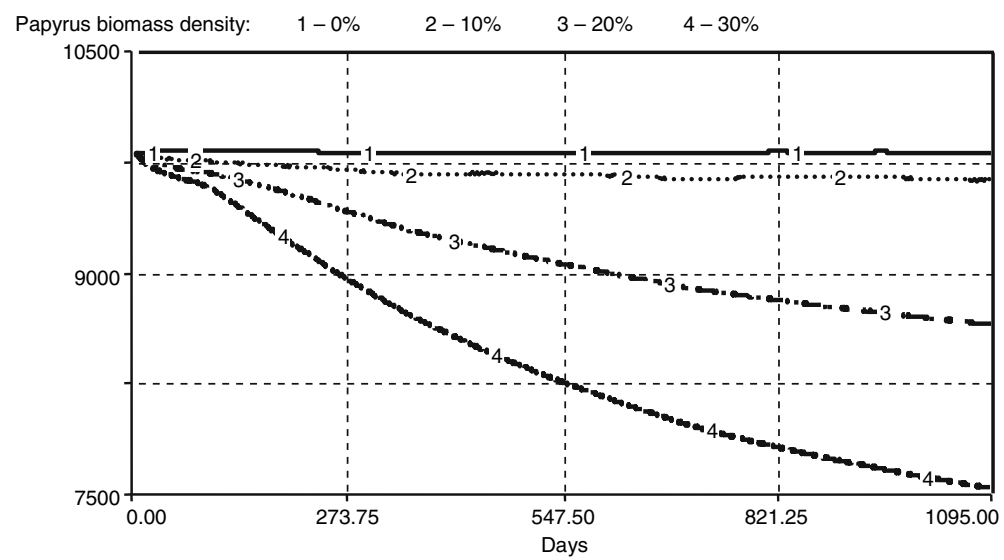

wetlands in East Africa (see review above). Primary productivity estimates in Kirinya wetland were approximately $8 \mathrm{~kg} \mathrm{dm} \mathrm{m}^{-2}$ year $^{-1}$ (Saunders et al. 2007), or about $329 \mathrm{mg} \mathrm{N} \mathrm{m}^{-2}$ year $^{-1}$ (assuming 1.5\% $\mathrm{N}$ in $\mathrm{dm}$ ). This is about twice the $160 \mathrm{mg} \mathrm{m}^{-2}$ year $^{-1}$ $\mathrm{N}$ uptake estimated by the model. The settling rates of organic nitrogen are within the ranges measured in Kirinya wetland (56-634 mg N m${ }^{-2} \mathrm{~d}^{-1}$; F. Kansiime
The nitrogen flows estimated by the model are well within the ranges measured in natural papyrus of nitrogen settling into the sludge was estimated at about $67 \mathrm{mg} \mathrm{N} \mathrm{m}^{-2} \mathrm{~d}^{-1}$.

\section{Discussion}


Fig. 8 Effect of harvesting (in $\%$ of biomass year ${ }^{-1}$ ) on the concentration of TAN in the water (in $\mathrm{g} \mathrm{m}^{-3}$ )
Table 3 Average internal flows $\left(\mathrm{mg} \mathrm{N} \mathrm{m}^{-2} \mathrm{~d}^{-1}\right)$ over a three-year period as calculated by the model for Kirinya wetland

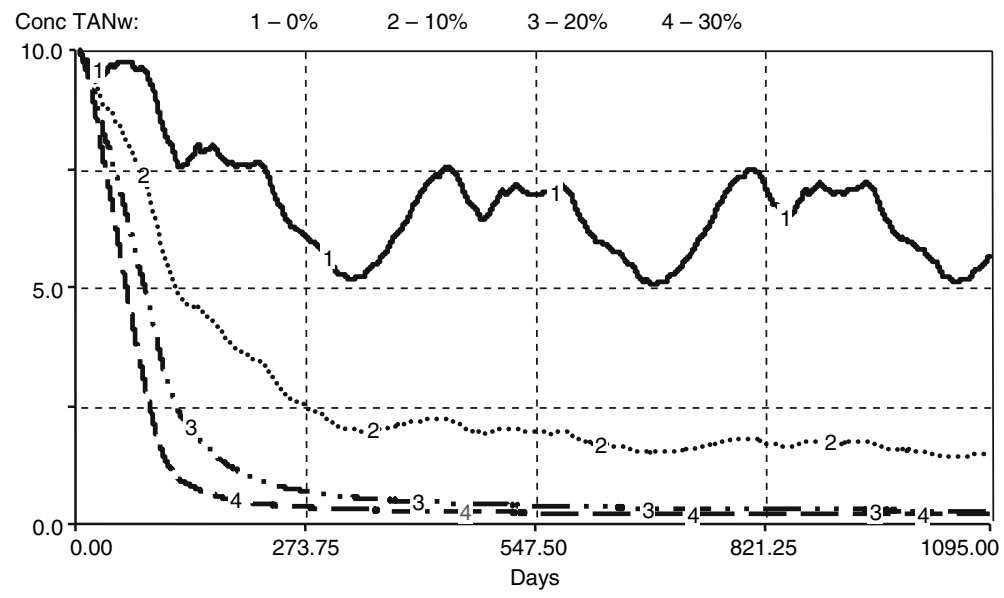

\begin{tabular}{|c|c|c|c|c|}
\hline \multirow[t]{2}{*}{ Process } & \multicolumn{4}{|c|}{ Harvesting $\left(\%\right.$ year $\left.^{-1}\right)$} \\
\hline & $0 \%$ year $^{-1}$ & $10 \%$ year $^{-1}$ & $20 \%$ year $^{-1}$ & $30 \%$ year $^{-1}$ \\
\hline Uptake NH4 & 127.3 & 177.1 & 195.7 & 198.8 \\
\hline Uptake NO3 & 34.6 & 19.6 & 13.7 & 12.3 \\
\hline Papyrus decay & 161.8 & 159.6 & 150.7 & 139.2 \\
\hline Mat sloughing and leaching & 122.5 & 122.0 & 120.4 & 118.2 \\
\hline Mat mineralization & 39.2 & 39.1 & 38.5 & 37.8 \\
\hline ONw settling & 67.6 & 67.4 & 67.0 & 66.4 \\
\hline ONw mineralization & 2.7 & 2.7 & 2.7 & 2.7 \\
\hline TANw nitrification & 22.2 & 8.7 & 3.5 & 2.4 \\
\hline ONsludge mineralization & 9.3 & 9.3 & 9.2 & 9.2 \\
\hline ONsludge burial & 46.3 & 46.3 & 46.2 & 46.1 \\
\hline TAN sludge diffusion to water & 0.4 & 3.7 & 5.2 & 5.5 \\
\hline TAN sludge diffusion to sediment & 0.2 & 0.0 & 0.0 & 0.0 \\
\hline TANw diffusion to sludge & 0.6 & 0.0 & 0.0 & 0.0 \\
\hline TANsed diffusion to sludge & 0.3 & 0.7 & 0.9 & 1.0 \\
\hline TAN sludge nitrification & 10.2 & 7.5 & 6.4 & 6.1 \\
\hline TAN sludge mineralization & 9.3 & 9.3 & 9.2 & 9.2 \\
\hline TANsed nitrification & 0.7 & 0.6 & 0.5 & 0.5 \\
\hline NO3 sludge diffusion to water & 7.5 & 5.8 & 5.0 & 4.8 \\
\hline NO3 sludge diffusion to sediment & 0.6 & 0.4 & 0.3 & 0.3 \\
\hline NO3w diffusion to sludge & 0.0 & 0.0 & 0.0 & 0.0 \\
\hline NO3sed diffusion to sludge & 0.0 & 0.1 & 0.1 & 0.1 \\
\hline
\end{tabular}

and P. Kelderman, unpublished results), albeit at the low end of the range. Perhaps the model is slightly conservative in its estimates of nitrogen uptake by the plants. This suggests that more nitrogen is taken up by the papyrus vegetation, but also more nitrogen is returned to the wetland through decomposition and sedimentation. Nitrogen burial in the sediment could not be compared to observed values, but was at the high end of the range of peat formation measured in eutrophic tropical wetlands (Vymazal 2001). In a permanently floating papyrus mat, water would not be expected to limit productivity at any time during the year. Seasonal differences in nutrient uptake and release rates might be caused by fluctuations in light intensity but these were not considered in this model. 
Denitrification was not reported in the simulation results. Denitrification was estimated although no direct measurements of denitrification from the wetland were available. However, due to the minor importance of nitrate in the system, denitrification did not have a significant contribution in the nitrogen budget. Some accumulation of nitrate in the model without denitrification was observed (Fig. 6). In a modelling study of Nyashishi wetland on Lake Victoria in Tanzania, denitrification was also found to be of minor importance (Mwanuzi et al. 2003). Denitrification may occur in the sediment, where anaerobic conditions occur and organic matter is readily available. It is not clear how much nitrate becomes available in the sediment because the anaerobic conditions present do not favour the nitrification process. Another location where denitrification may occur is the papyrus mat, where localised aerobic conditions are followed by anaerobic conditions, favouring nitrification and denitrification. More research is needed to measure directly the denitrification process in papyrus wetlands. The same applies to volatilization of ammonia, nitrogen fixing and the nitrogen input from rainfall.

The model emphasizes the importance of organic nitrogen in the wetland. Its accumulation leads to low oxygen concentrations, and hence reduced nitrification and probably also mineralization rates, thus reinforcing organic nitrogen accumulation. The model does not provide for the discharge of sludge into the lake but in reality sludge may be flushed out of the wetland during the rainy season when hydraulic flows increase. In addition to wetland flushing, resuspension of the sludge will also affect the nitrogen dynamics of the system. More data on the dynamics of particulate and dissolved nitrogen in the wetland are needed to improve the model. The modelling study of Mwanuzi et al. (2003) showed that the wetland had a negative retention of total nitrogen because of the large export of organic nitrogen. In the model of Kirinya wetland, which does not consider flushing out of the sludge, $75 \%$ of the nitrogen flowing into the wetland flows out into the lake and only $25 \%$ is retained in the wetland (Table 2).

The logistic model for nitrogen uptake results in very low nitrogen accumulation when the plants are close to their carrying capacity. Nutrients taken up in this stationary growth phase are merely replacing the nutrients lost by natural mortality and decay of the plants. In this way the model reflects the situation in the field where both space and light for new shoots in a mature stand of papyrus are very limited. Reducing the biomass of the vegetation leads to regenerative growth and is accompanied by an increase in the nutrient uptake. This happens when an area of papyrus is harvested completely and numerous new shoots develop rapidly from the floating mat. It takes about one year for a papyrus stand to regenerate after complete harvesting. This mechanism was shown in the model by the increased nitrogen uptake rates with harvesting of the plants (Table 3) and the increase in nitrogen retention from 21.5 to $32.3 \mathrm{~g} \mathrm{~m}^{-2}$ year ${ }^{-1}$ (at $10 \%$ year $^{-1}$ harvesting; Table 2). At higher harvesting rates, uptake and retention do not increase proportionally. This is caused by the reduction of plant biomass (which immediately leads to lower uptake; see Eq. 2) and also by the reduction in dissolved nutrients leading to nutrient limitation. Harvesting thus seems to be a good strategy to increase the nitrogen retention capacity of the wetland, but care should be taken to develop sustainable harvesting regimes. The current model suggests that annual harvesting should remove between $10 \%$ and $20 \%$ of the total papyrus biomass. The impact of harvesting on phosphorus retention is likely to be lower because the phosphorous content of papyrus plants is much lower than nitrogen content (Gaudet 1975) and because phosphorous is bound tightly to the sediment resulting in less recycling of phosphorous within the system than nitrogen (Kelderman et al. 2007).

The model may be used to evaluate the effects of nutrient uptake by other wetland plant species (e.g., Miscanthidium) and agricultural crops (e.g., Dioscorea spp., Ipomoea batatas L., etc.). Each plant species has characteristic nitrogen uptake and release patterns. The mat structure of Miscanthidium is also completely different (Azza et al. 2000). Although crop harvesting may have a positive impact on nitrogen retention of the wetland, the changes to wetland hydrology and structure when used for agriculture may influence its capacity to retain nutrients compared to the sustainable harvesting of the natural wetland vegetation. 
Generally, the model results of biomass estimation and nutrient concentrations were in the range measured in the field. However, the plant growth model is descriptive and does not allow modelling of $\mathrm{N}$ partitioning between the standing and root/rhizome biomass. Data from Kirinya and Nakivubo wetlands show the existence of preferential wastewater flow paths in the wetlands, resulting in a reduction in the effective surface area of wetland vegetation. If the model is to be used for estimation of the N-retention capacity of other Lake Victoria wetlands, these effects should be taken into consideration. There is a lack of data on the settling and outflow of detritus in the wetland, as well as on denitrification and volatilization. Denitrification and accumulation of organic $\mathrm{N}$ are the key processes determining $\mathrm{N}$ retention in these wetlands and therefore should be developed further within the model. Finally, a separate model for rooted papyrus stands is needed because of the fundamental differences in the processes of nutrient uptake between floating and rooted papyrus vegetation.

\section{Conclusions}

The current model estimates maximum nitrogen retention in floating papyrus wetlands at $25 \mathrm{~g} \mathrm{~m}^{-2}$ year $^{-1}$ or about $25 \%$ of nitrogen input. Actual nitrogen retention is probably lower because organic nitrogen accumulated in the sludge may be washed out during the rainy season. Nitrogen retention will be higher and nutrient concentrations in the wetland water lower when papyrus biomass is reduced, e.g. by harvesting papyrus culms. The model can be improved by incorporating (currently lacking) data on the dynamics of detritus and on nitrogen losses in papyrus wetlands.

Acknowledgement This research was carried out within the framework of the ECOTOOLS project, supported by the European Commission RTD INCO programme (ICA4CT 2001-10036).

\section{References}

Azza NGT, Kansiime F, Nalubega M, Denny P (2000) Differential permeability of papyrus and Miscanthidium root mats in Nakivubo swamp, Uganda. Aquat Bot 67:169-178
Delincé G (1992) The ecology of the fish pond ecosystem with special reference to Africa. Kluwer Academic Publishers, Dordrecht, The Netherlands, p 230

Denny P, Kipkemboi J, Kaggwa R, Lamtane H (2006) The potential of Fingerpond systems to increase food production from wetlands in Africa. Int $\mathrm{J}$ Ecol Environ Sci 32:41-47

Gaudet JJ (1975) Mineral concentrations in papyrus in various African swamps. J Ecol 63:483-491

Gaudet JJ (1977) Uptake, accumulation, and loss of nutrients by papyrus in tropical swamps. Ecology 58:415-422

Gaudet JJ (1979) Seasonal changes in nutrients in a tropical swamp: North swamp, Lake Naivasha, Kenya. J Ecol 67:953-981

Gichuki J, Dahdouh Guebas F, Mugo J, Rabuor CO, Triest L, Derhairs F (2001) Species inventory and the local uses of the plants and fishes of the Lower Sondu Miriu wetland of Lake Victoria, Kenya. Hydrobiologia 458:99-106

Jamu DM (1998) Modeling organic matter and nitrogen dynamics in integrated aquaculture/agriculture systems: effects of cycling pathways on nitrogen retention and system productivity. $\mathrm{PhD}$ thesis, University of California, Davis, USA

Jamu DM, Piedrahita RH (2002) An organic matter and nitrogen dynamics model for the ecological analysis of integrated agriculture/aquaculture systems. I. Model development and calibration. Environ Model Software 17:571-582

Jiménez-Montealegre R, Verdegem MCJ, van Dam AA, Verreth JAJ (2002) Conceptualization and validation of a dynamic model for the simulation of nitrogen transformation and fluxes in fishponds. Ecol Model 147:123-152

Jimenez-Montealegre RA (2001) Nitrogen transformation and fluxes in fishponds, $\mathrm{PhD}$-thesis, Wageningen University, Wageningen, The Netherlands

Jones MB, Muthuri FM (1985) The canopy structure and microclimate of papyrus (Cyperus papyrus) swamps. J Ecol 73:481-491

Jones MB, Muthuri FM (1997) Standing biomass and carbon distribution in a papyrus (Cyperus papyrus L.) swamp on Lake Naivasha, Kenya. J Trop Ecol 13:347-356

Jørgensen SE, Bendoricchio G (2001) Fundamentals of ecological modeling. Elsevier, Amsterdam

Kaggwa RC, Kansiime F, Denny P, van Dam AA (2005) A preliminary assessment of the aquaculture potential of two wetlands located in the northern shores of Lake Victoria, Uganda. In: Vymazal J (ed) Natural and constructed wetlands: nutrients, metals and management. Backhuys Publishers, Leiden (The Netherlands), pp 350-368

Kansiime F, Mwesigye P (2003) Variation of water quality in the stabilisation ponds and Kirinya West Wetland in JinjaUganda. Afr J Trop Hydrobiol Fisheries (in press)

Kansiime F, Nalubega M (1999) Wastewater treatment by a natural wetland: the Nakivubo swamp, Uganda. $\mathrm{PhD}$ thesis, A.A. Balkema Publishers, Rotterdam, Netherlands

Kelderman P, Kansiime F, Tola MA, van Dam AA (2007) The role of sediments for phosphorus retention in the Kirinya wetland (Uganda) (this volume)

Kipkemboi J, Kansiime F, Denny P (2002) The response of Cyperus papyrus (L.) and Miscanthidium violaceum 
(K. Schum.) Robyns to eutrophication in natural wetlands of Lake Victoria, Uganda. Afr J Aquat Sci 27:11-20

Kipkemboi J, van Dam AA, Denny P (2006) Towards sustainable community-wetland interaction: a pilot study on enhancing contribution to livelihoods through integrated aquaculture production systems (Fingerponds) at the Lake Victoria wetlands, Kenya. Wetlands, water and livelihoods workshop, St Lucia, South Africa, January 30February 2, 2006. Wageningen, Wetlands International

McCartney MP, Musiyandima M, Houghton-Carr HA (2005) Working wetlands: Classifying wetland potential for agriculture. Research Report 90. Colombo, Sri Lanka: International Water Management Institute (IWMI)

Muthuri FM, Jones MB (1997) Nutrient distribution in a papyrus swamp: Lake Naivasha, Kenya. Aquat Bot 56:35-50

Muthuri FM, Jones MB, Imbamba SK (1989) Primary productivity of papyrus (Cyperus papyrus) in a tropical swamp; Lake Naivasha, Kenya. Biomass 18:1-14

Mwanuzi F, Aalderink H, Mdamo L (2003) Simulation of pollution buffering capacity of wetlands fringing the Lake Victoria. Environ Int 29:95-103
Odada EO, Olago DO, Kulindwa K, Ntiba M, Wandiga S (2004) Mitigation of environmental problems in Lake Victoria, East Africa: causal chain and policy options analysis. Ambio 33:13-23

Okeyo-Owuor JB (1999) A review of biodiversity and socioeconomics research in relation to fisheries in Lake Victoria. IUCN Eastern Africa Programme, Nairobi, p 77

Okurut TO (2000) A pilot study on municipal wastewater treatment using constructed wetlands in Uganda. $\mathrm{PhD}$ thesis IHE Delft, A.A. Balkema, Rotterdam

Saunders M, Kansiime F, Jones MB (2007) Biomass and productivity of C. papyrus dominated wetlands (this volume)

Thompson K, Shewry PR, Woolhouse HW (1979) Papyrus swamp development in the Upemba: studies of population structure in Cyperus papyrus stands. Bot J Linnean Soc 78:299-316

Vymazal J (2001) Types of constructed wetlands for wastewater treatment: their potential for nutrient removal. In: Vymazal J (ed) Transformations of nutrients in natural and constructed wetlands. Backhuys Publishers, Leiden, pp 1-93 